\title{
SUITABILITY OF SULFUR AS MODIFIER IN BITUMEN FOR ROAD CONSTRUCTION
}

\author{
Poorna Prajna $\mathbf{S}^{1}$, Mohamed Ilyas Anjum² \\ ${ }^{1}$ Research Scholar \& Assistant Professor, Department of Civil Engineering, Ghousia College of Engineering, \\ Ramanagaram-562159, Karnataka, India. Mobile: 09986807991 \\ ${ }^{2}$ Professor \& Head, Department of Civil Engineering, Ghousia College of Engineering, Ramanagaram-562159, \\ Karnataka, India, Mobile: 09845588477
}

\begin{abstract}
The design of a satisfactory bituminous mix is a complex task due to the wide variation in properties of its constituents such as bitumen, coarse and fine aggregate, filler, etc. The design also depends on the shape and gradation of the aggregates. Flexible pavement with bituminous surfacing is commonly used in Indian highways. Distress symptoms, such as cracking, rutting, etc., are increasingly caused earlier by high traffic intensity, over loading of vehicles and significant variations in daily and seasonal temperature of the pavement. Investigations have revealed that modifiers can be used to improve properties of bitumen and bituminous mixes to make it more suitable for road construction. Also there are many other materials that may be tried as modifiers in bitumen. This paper reports an investigation carried out on Bituminous Concrete mixes corresponding to grade-1, prepared using midpoint gradation for aggregate combined index of 30\% using Sulphur as modifier. The conventional Marshall Stability test was conducted on the specimens as per ASTM D 1559. The present investigation comprises of determining the Marshall test properties of Bituminous Concrete Mixes Using 60/70 penetration grade bitumen modified with Sulphur as Modifier. The study helps to ascertain the suitability of Sulfur as modifier which could minimize the consumption of plain bitumen.
\end{abstract}

Keywords: Bituminous Concrete mixes, combined index, Marshall Stability test, Sulfur, Mid-point gradation, 60/70 penetration grade bitumen.

\section{INTRODUCTION}

Around 98 percent of the total roads network constitute the flexible roads, where in bitumen is used as a binder. Conventional bituminous materials have generally performed satisfactorily in most highway pavement and airfield runway applications. However in recent years, severe climates, increased traffic levels, larger and heavier trucks with new axle designs and high tyre pressures, have seemed to add to severe demands of load and environment on the highway system. This has resulted in the need to enhance the properties of existing asphalt material. Polymer modification offers one solution to overcome the deficiencies of bitumen and thereby improve the performance of asphalt mixtures. Polymer modification offers solution to improve permanent deformation, fatigue life, thermal cracking resistance, wear resistant and ageing of existing asphalt materials.

Polymers are being increasingly used to modify bitumen and to enhance the properties of bituminous mixes. The polymer modified binders are highly suitable for special applications, where traffic is extremely high. However climatic and mixing temperature play important role in the preparation of polymer modifier binder.

Some of the polymers which are compatible with bitumen and which are easily available in market are StyreneButadiene-Styrene (SBS), Styrene-Butadiene-Rubber (SBR) and Ethylene Vinyl Acetate (EVA). The mix prepared with these modifiers shows a higher resistance to permanent deformation at higher temperature, increased fatigue life, improved temperature susceptibility and reduced cracking potential at lower temperature compared to the conventional bitumen.

The modified bitumen and the mixes prepared out of these modified bitumen should possess better strength characteristics compared to the mixes with plain bitumen. This aspect is studied in the present investigation.

Some of the properties of bituminous mixes that can be improved using polymers are: increased resistance to stripping $^{[1]}$; reduce the effect of bleeding of binder during peak summer ${ }^{[1]}$, Aging $^{[1]}$ and skid-resistance characteristics are improved; improvement in toughness ${ }^{[2]}$; increase in tenacity ${ }^{[3,4]}$; resistance to creep deformation ${ }^{[5,6]}$; increase in indirect tensile strength ${ }^{[7]}$ and compressive strength ${ }^{[7]}$; decrease the rutting rate ${ }^{[8,9]}$; increase the fatigue resistance ${ }^{[10,11,12]}$; improve the temperature susceptibility; increase in Marshall stability ${ }^{[13,14,15]}$, reduces the porosity, absorption of moisture and improves soundness; improvement in skid resistance characteristics ${ }^{[16]}$; increases the melting point ${ }^{[17]}$; improves the viscosity and elasticity of the materials tested ${ }^{[18]}$; improve the resistance to abrasion at low and high temperature; decrease the brittleness ${ }^{[19]}$. 


\subsection{Object of the Present Study}

The objectives of the present study are

1) To determine the Marshall Test properties of Bituminous concrete mixes using 60/70 penetration grade bitumen modified using Sulphur.

2) To study the effect of Sulphur as modifier in various proportions in bituminous mixes.

\section{MATERIALS USED}

\subsection{Aggregates}

The required quantity of aggregates consisting of assorted sizes was collected from a nearby quarry. The quarry is situated just $2 \mathrm{~km}$ away from south-west of Bidadi and its longitude and latitude is $12^{\circ} 47^{\prime} 24^{\prime \prime} \mathrm{N}$ and $77^{\circ} 21^{\prime} 49^{\prime \prime} \mathrm{E}$ respectively. The aggregates have been crushed from the rock which is medium grained, mesocratic (grayish black) showing granitic structure. The essential minerals are Quartz, Feldspar and Biotite Mica and minor mineral is Hornblende. It is also contains accessory minerals like magnetite. It is an oversaturated acid plutonic igneous rock. It has low specific gravity and very hard. Based on the above observation, the rock is identified as granite.

\subsection{Bitumen}

The Bitumen of 60/70 penetration grade which was supplied by Mangalore Refinery and Petrochemicals Limited (MRPL) was used.

\subsection{Modifier}

The Sulphur colloidal powder is brownish grey in colour and is a mixture of $75 \%$ sulphur and $25 \%$ acacia (gum Arabic), is utilized as a protective colloid. It is tried as a modifier in most of the bituminous road constructions. So here, effort is made to minimize the cost of bituminous road upto some extent by using sulphur as a modifier along with bitumen

\section{METHODOLOGY}

\subsection{Determination of Aggregate Shape Factors}

Flakiness and Elongation index was determined as per the procedure laid down by IS: 2386 part-I. The aggregates were sieved into fractions such as 26.5-19, 19-13.2 and $13.2-9.5 \mathrm{~mm}$ using a gyratory coarse aggregate mechanical sieve shaker. The weight of aggregate in each fraction was found. Using the thickness gauge, each aggregate in the first fraction was passed along its thickness through the respective opening. The flaky aggregate passing through the respective openings were separated and weighed. Using the length gauge, each aggregate retained on thickness gauge was passed along its length through the respective opening. The elongated aggregate retained in the respective openings were separated. Similarly the elongated aggregates in the other fractions were separated.

\subsection{Preparation of Marshall Dry Mix}

Table - 1: Composition of Bituminous Concrete Pavement Layers (MoRTH-2001)

\begin{tabular}{|l|l|l|}
\hline Grading aggregate & 1 & 2 \\
\hline $\begin{array}{l}\text { Nominal } \\
\text { size }\end{array}$ & $19 \mathrm{~mm}$ & $13 \mathrm{~mm}$ \\
\hline Layer thickness & $50-65 \mathrm{~mm}$ & $30-45 \mathrm{~mm}$ \\
\hline IS Sieve (mm) & $\begin{array}{l}\text { Cumulative \% by weight of } \\
\text { total aggregate passing }\end{array}$ \\
\hline 45 & - & - \\
\hline 37.5 & - & - \\
\hline 26.5 & 100 & - \\
\hline 19 & $79-100$ & 100 \\
\hline 13.2 & $59-79$ & $79-100$ \\
\hline 9.5 & $52-72$ & $70-88$ \\
\hline 4.75 & $35-55$ & $53-71$ \\
\hline 2.36 & $28-44$ & $42-58$ \\
\hline 1.18 & $20-34$ & $34-48$ \\
\hline 0.6 & $15-27$ & $26-38$ \\
\hline 0.3 & $10-20$ & $18-28$ \\
\hline 0.15 & $5-13$ & $12-20$ \\
\hline 0.075 & $2-8$ & $4-10$ \\
\hline $\begin{array}{l}\text { Bitumen content \% } \\
\text { by mass of total mix }\end{array}$ & $5.0-6.0$ & $5.0-7.0$ \\
\hline Bitumen grade (pen.) & 65 & 65 \\
\hline & & \\
\hline
\end{tabular}

\subsection{Calculation of Weight of Aggregates of} Different Fractions

Table - 2: Percentage of Aggregates Retained on each Sieve

\begin{tabular}{|l|l|l|l|}
\hline $\begin{array}{l}\text { IS } \\
\text { Sieve } \\
(\mathrm{mm})\end{array}$ & $\begin{array}{l}\text { Percentage } \\
\text { passing }\end{array}$ & $\begin{array}{l}\text { Mid-point of } \\
\text { percentage } \\
\text { passing }\end{array}$ & $\begin{array}{l}\text { Percentage } \\
\text { retained }\end{array}$ \\
\hline 26.5 & 100 & - & - \\
\hline 19 & $79-100$ & 89.5 & 10.5 \\
\hline 13.2 & $59-79$ & 69 & 20.5 \\
\hline 9.5 & $52-72$ & 62 & 7 \\
\hline 4.75 & $35-55$ & 45 & 17 \\
\hline 2.36 & $28-44$ & 36 & 9 \\
\hline 1.18 & $20-34$ & 27 & 9 \\
\hline 0.6 & $15-27$ & 21 & 6 \\
\hline 0.3 & $10-20$ & 15 & 6 \\
\hline 0.15 & $5-13$ & 9 & 6 \\
\hline 0.075 & $2-8$ & 5 & 4 \\
\hline
\end{tabular}

Table - 3: Quantity of Aggregates for Dry Mix Preparation

\begin{tabular}{|l|l|l|l|l|}
\hline $\begin{array}{l}\text { IS Sieve } \\
(\mathrm{mm})\end{array}$ & $\begin{array}{l}\text { Weight } \\
\text { of FA } \\
(\mathrm{g})\end{array}$ & $\begin{array}{l}\text { Weight } \\
\text { of EA } \\
(\mathrm{g})\end{array}$ & $\begin{array}{l}\text { Weight } \\
\text { of } \\
\text { NF-NE } \\
(\mathrm{g})\end{array}$ & $\begin{array}{l}\text { Total } \\
\text { weight } \\
\text { aggregates } \\
(\mathrm{g})\end{array}$ \\
\hline $26.5-19$ & 18.90 & 18.90 & 88.20 & 126.00 \\
\hline $19-13.2$ & 36.90 & 36.90 & 172.20 & 246.00 \\
\hline $13.2-9.5$ & 12.60 & 12.60 & 58.80 & 84.00 \\
\hline $9.5-4.75$ & - & - & - & 204.00 \\
\hline $4.75-2.36$ & - & - & - & 108.00 \\
\hline $2.36-1.18$ & - & - & - & 108.00 \\
\hline
\end{tabular}




\begin{tabular}{|l|l|l|l|l|}
\hline $1.18-0.6$ & - & - & - & 72.00 \\
\hline $0.6-0.3$ & - & - & - & 72.00 \\
\hline $0.3-0.15$ & - & - & - & 72.00 \\
\hline $\begin{array}{l}0.15- \\
0.075\end{array}$ & - & - & - & 48.00 \\
\hline $\begin{array}{l}0.075- \\
\text { pan }\end{array}$ & - & - & - & 60.00 \\
\hline
\end{tabular}

The dry mix was prepared based on mid-point gradation for combined index of $30 \%$, using aggregates of different sizes from $26.5,19,13.2,9.5,4.75,2.36,1.18,0.6,0.3,0.15$, $0.075 \mathrm{~mm}$ and Marshall powder (passing on IS $0.075 \mathrm{~mm}$ and retained on Pan) confirming to grade-1 as per MoRTH2001 shown in Table 1. Required quantity of aggregates consisting Flaky Aggregates (FA), Elongated Aggregates (EA) and Non Flaky- Non Elongated Aggregates (NF-NE) was mixed to prepare dry mix weighing $1200 \mathrm{~g}$ each, shown in Table 3. Shape test is not applicable for aggregates size less $6.5 \mathrm{~mm}$.

\subsection{Preparation of Marshall Test Specimens}

Approximately $1200 \mathrm{~g}$ of the aggregate consisting of different aggregate fractions, as worked out earlier, was preheated to $175-190^{\circ} \mathrm{C}$. The bitumen (plain/modified) was heated to $121-138^{\circ} \mathrm{C}$ and the first trial bitumen content was added to a preheated steel bowl. The mix was thoroughly mixed at mixing temperature about $154^{\circ} \mathrm{C}$. The mix was compacted in a preheated Marshall mould by applying 75 blows on each face of the specimen.

Specimens were prepared at bitumen content $4.5 \%, 5 \%$, $5.5 \%, 6 \%$ and $6.5 \%$ weight of dry mix modified using Sulfur at $3 \%, 6 \%, 9 \%$ and $12 \%$ weight of bitumen respectively.

\section{RESULTS AND ANALYSIS}

The Marshall Stability test was conducted on the prepared specimens as per ASTM D 1559 to determine the stability and flow values. The Marshall Test properties such as bulk density, Volume of air voids, volume of bitumen, voids in Mineral aggregates, etc were determined, shown in Table 4.

Table - 4: Marshall Test Properties of Bituminous Concrete Mixes Using Sulfur Modified Bitumen

\begin{tabular}{|c|c|c|c|c|c|c|c|c|c|}
\hline $\begin{array}{l}\text { Modifier } \\
\text { Content } \\
\%\end{array}$ & $\begin{array}{l}\text { Bulk } \\
\text { Density } \\
\text { (Gb) g/cc }\end{array}$ & $\begin{array}{l}\text { Theoretical } \\
\text { Density } \\
\text { (Gt) } \\
\text { g/cc }\end{array}$ & $\begin{array}{l}\text { Volume } \\
\text { of Air } \\
\text { Voids } \\
(\mathrm{Vv}) \\
\%\end{array}$ & $\begin{array}{l}\text { Volume } \\
\text { of } \\
\text { Bitumen } \\
(\mathrm{Vb}) \\
\%\end{array}$ & $\begin{array}{l}\text { Voids in } \\
\text { Mineral } \\
\text { Aggregates } \\
\text { (VMA) } \\
\%\end{array}$ & $\begin{array}{l}\text { Voids } \\
\text { Filled } \\
\text { with } \\
\text { Bitumen } \\
\text { (VFB) } \\
\%\end{array}$ & $\begin{array}{l}\text { Marshall } \\
\text { Stability } \\
\text { (S) } \\
\mathrm{kN}\end{array}$ & $\begin{array}{l}\text { Flow } \\
(\mathrm{F}) \\
\mathrm{mm}\end{array}$ & $\begin{array}{l}\text { Marshall } \\
\text { Quotient } \\
\mathrm{kg} / \mathrm{mm}\end{array}$ \\
\hline \multicolumn{10}{|c|}{ Bitumen Content $4.5 \%$} \\
\hline 0 & 2.38 & 2.47 & 3.17 & 10.29 & 14.00 & 77.27 & 15.64 & 2.00 & 797.15 \\
\hline 3 & 2.38 & 2.49 & 4.21 & 10.29 & 14.51 & 70.27 & 22.79 & 2.83 & 820.92 \\
\hline 6 & 2.39 & 2.49 & 4.27 & 10.13 & 14.38 & 57.64 & 18.75 & 2.27 & 842.02 \\
\hline 9 & 2.37 & 2.46 & 3.83 & 11.12 & 15.04 & 62.28 & 26.88 & 3.05 & 898.41 \\
\hline 12 & 2.36 & 2.46 & 2.73 & 11.61 & 14.70 & 71.69 & 19.78 & 3.83 & 526.47 \\
\hline \multicolumn{10}{|c|}{ Bitumen Content $5.0 \%$} \\
\hline 0 & 2.40 & 2.47 & 2.84 & 10.78 & 13.68 & 79.19 & 18.91 & 2.60 & 79.57 \\
\hline 3 & 2.41 & 2.49 & 3.53 & 10.30 & 13.67 & 77.10 & 23.68 & 3.90 & 618.96 \\
\hline 6 & 2.40 & 2.49 & 3.62 & 10.21 & 13.85 & 62.45 & 21.49 & 3.27 & 669.91 \\
\hline 9 & 2.38 & 2.46 & 2.73 & 11.36 & 14.24 & 63.87 & 30.22 & 3.65 & 844.01 \\
\hline 12 & 2.37 & 2.46 & 2.21 & 11.66 & 13.85 & 72.92 & 21.99 & 4.20 & 533.73 \\
\hline \multicolumn{10}{|c|}{ Bitumen Content $5.5 \%$} \\
\hline 0 & 2.42 & 2.47 & 2.33 & 10.87 & 13.26 & 79.50 & 22.76 & 3.20 & 725.05 \\
\hline 3 & 2.42 & 2.49 & 2.78 & 10.34 & 13.53 & 78.17 & 26.30 & 4.30 & 623.49 \\
\hline 6 & 2.42 & 2.49 & 3.35 & 10.24 & 13.70 & 62.54 & 24.60 & 4.40 & 569.94 \\
\hline 9 & 2.42 & 2.46 & 1.94 & 11.43 & 13.37 & 69.05 & 24.86 & 4.90 & 517.19 \\
\hline 12 & 2.41 & 2.46 & 1.55 & 11.77 & 13.71 & 75.60 & 22.38 & 4.75 & 480.30 \\
\hline \multicolumn{10}{|c|}{ Bitumen Content $6.0 \%$} \\
\hline 0 & 2.41 & 2.47 & 2.09 & 10.87 & 13.21 & 79.91 & 21.71 & 3.40 & 650.92 \\
\hline 3 & 2.41 & 2.49 & 2.65 & 10.37 & 13.50 & 85.00 & 24.59 & 4.60 & 544.94 \\
\hline 6 & 2.40 & 2.49 & 3.1 & 10.27 & 13.62 & 63.38 & 21.89 & 4.50 & 495.88 \\
\hline 9 & 2.38 & 2.46 & 1.91 & 11.43 & 13.27 & 69.19 & 20.02 & 5.80 & 351.87 \\
\hline 12 & 2.37 & 2.46 & 1.47 & 11.82 & 13.67 & 76.33 & 21.03 & 5.10 & 420.35 \\
\hline
\end{tabular}




\begin{tabular}{|l|l|l|l|l|l|l|l|l|l|}
\hline \multicolumn{1}{|l|}{ Bitumen Content 6.5\% } \\
\hline 0 & 2.40 & 2.47 & 2.00 & 10.89 & 13.14 & 80.03 & 14.28 & 5.00 & 291.14 \\
\hline 3 & 2.38 & 2.49 & 2.60 & 10.38 & 13.30 & 89.47 & 17.65 & 5.10 & 352.79 \\
\hline 6 & 2.38 & 2.49 & 2.48 & 10.29 & 13.57 & 65.70 & 21.70 & 5.40 & 409.65 \\
\hline 9 & 2.37 & 2.46 & 1.66 & 11.46 & 13.12 & 73.33 & 19.98 & 5.90 & 345.21 \\
\hline 12 & 2.35 & 2.46 & 1.00 & 11.84 & 13.50 & 76.71 & 21.03 & 5.20 & 412.27 \\
\hline
\end{tabular}

Graphs are plotted taking Marshall test properties along Yaxis and bitumen content along $\mathrm{X}$-axis for various Sulfur content which is as shown in the Figure 1- 8

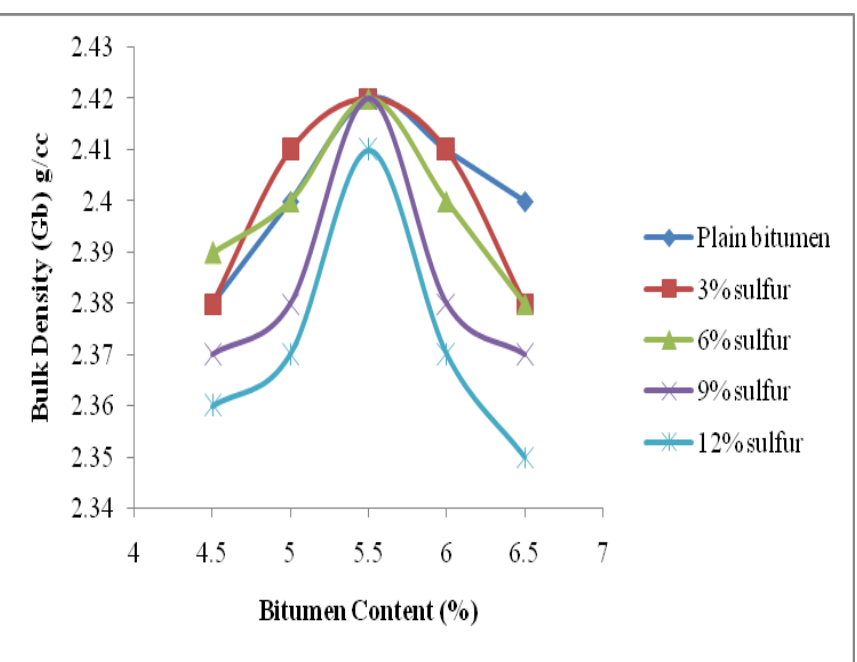

Fig - 1 : Bulk density Vs Bitumen content

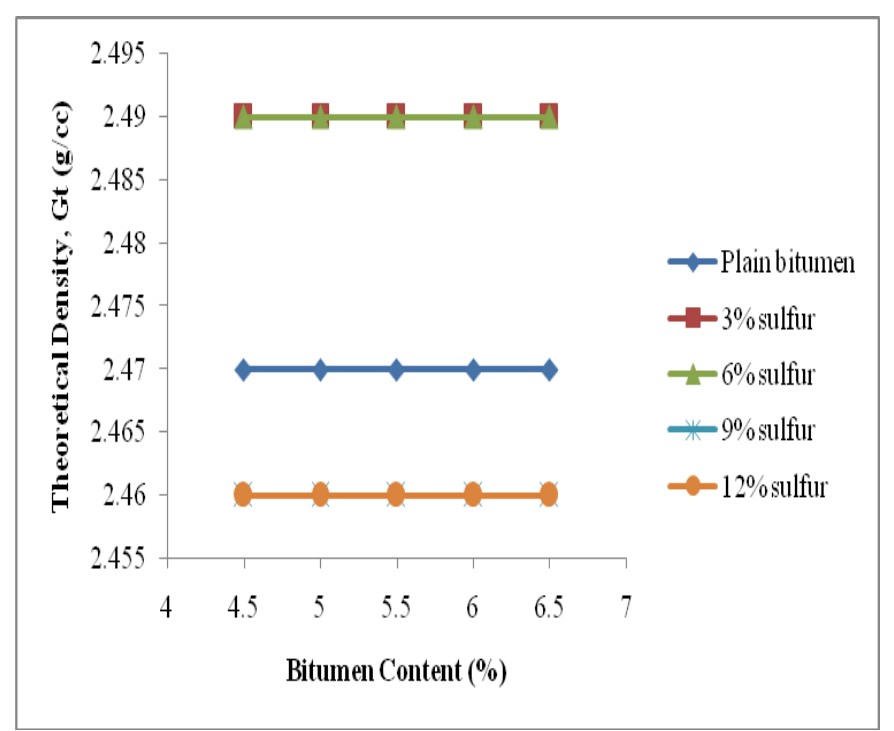

Fig - 2 : Theoritical density Vs Bitumen content

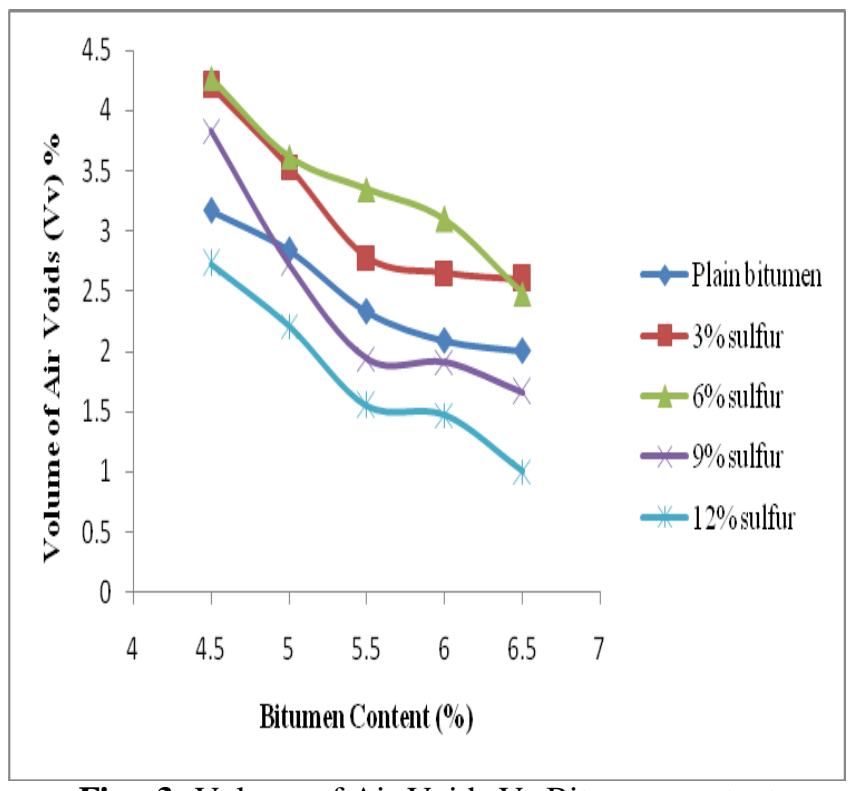

Fig - 3: Volume of Air Voids Vs Bitumen content

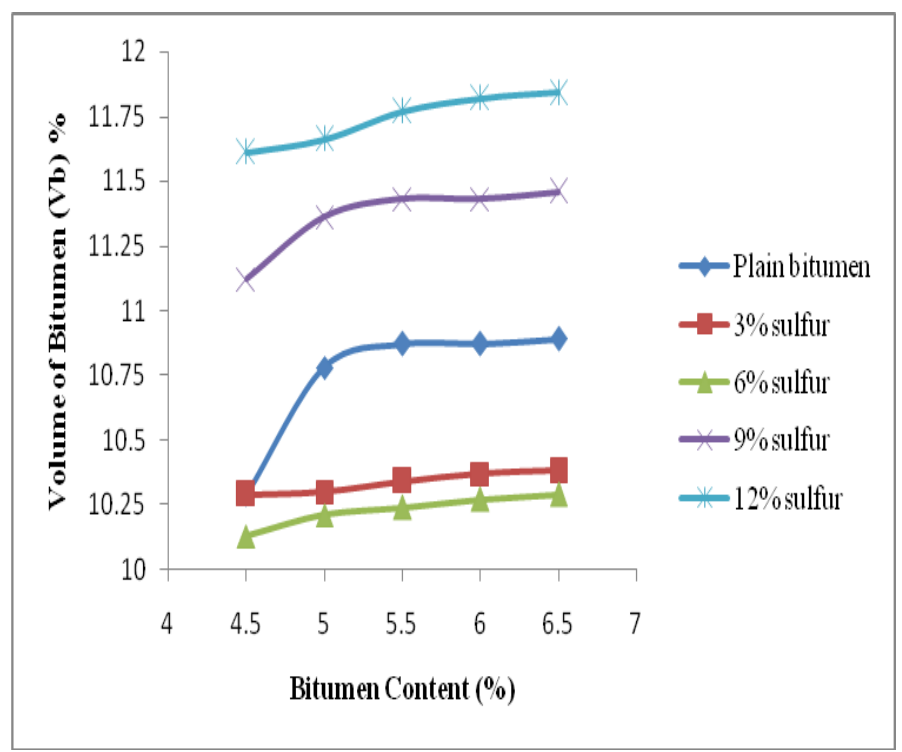

Fig - 4: Volume of Bitumen Vs Bitumen content 


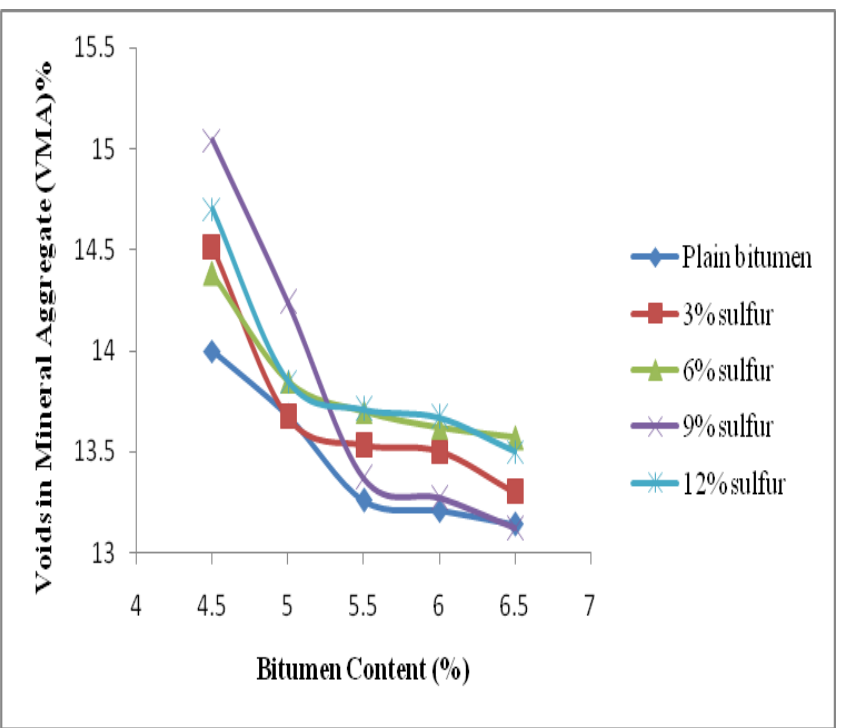

Fig - 5: Voids in Mineral Aggregate Vs Bitumen content

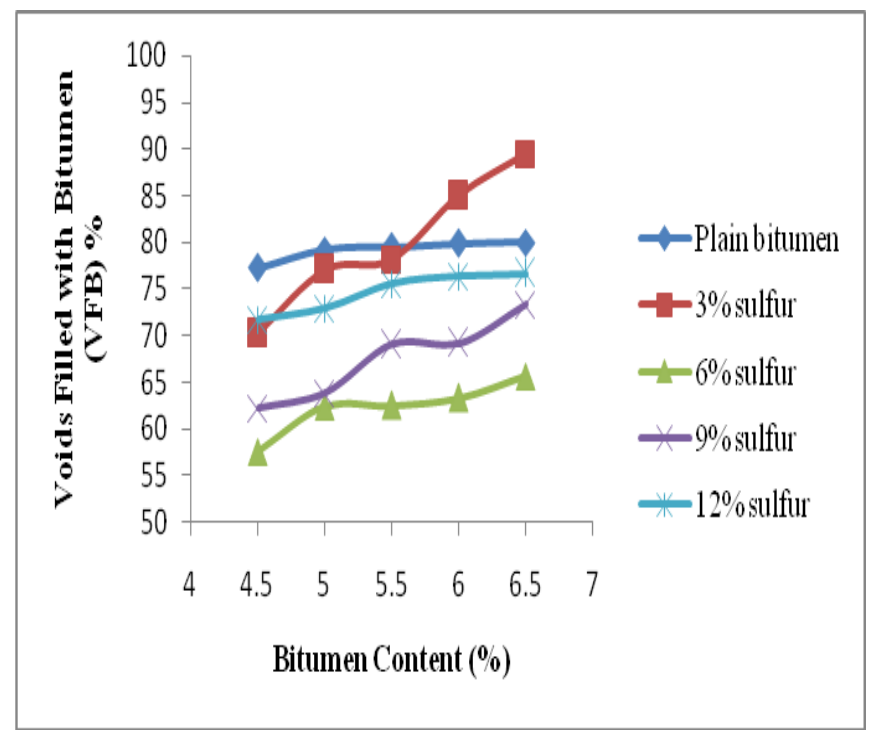

Fig - 6: Voids Filled with Bitumen Vs Bitumen content

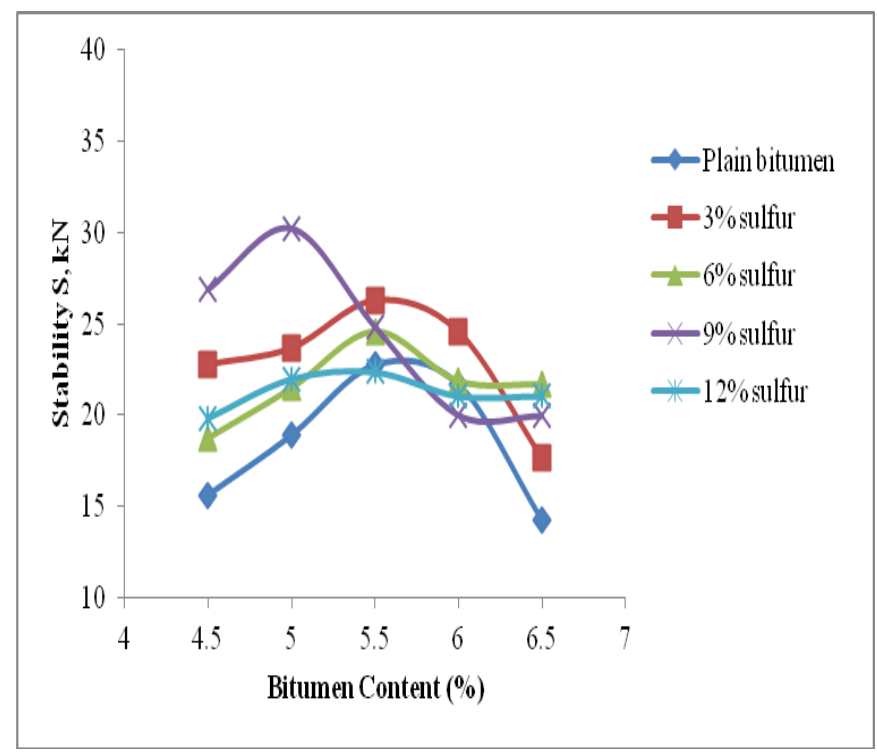

Fig - 7: Stability Vs Bitumen content

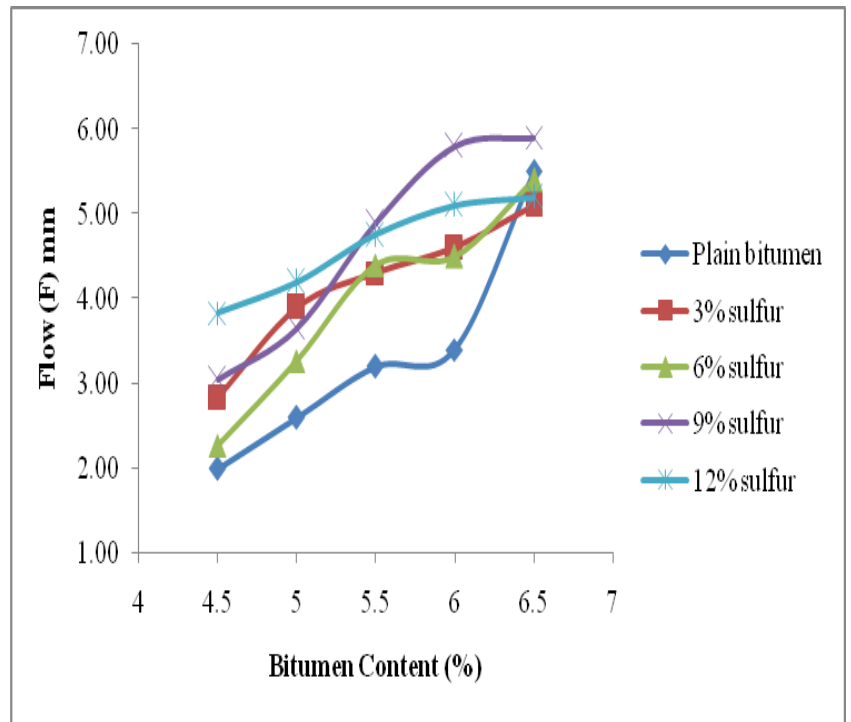

Fig - 8: Flow Vs Bitumen content

\section{DISCUSSION}

In this section, the properties such as bulk density, theoretical density, volume of air voids, volume of bitumen, VMA, VFB, Marshall Stability, flow and Marshall Quotient values were analyzed for sulfur modified bituminous mix in varying proportion $3 \%, 6 \%, 9 \%$ and $12 \%$ for $4.5 \%, 5 \%$, $5.5 \%, 6 \%$ and $6.5 \%$ bitumen content, are presented in Table 4 and shown in Figs 1 to 8 . All these properties are indicators of the performance of bituminous concrete mix in the field. In the sight of the usefulness of the addition of modifiers, the following discussions are presented.

From the above results it is observed when the percentage of sulfur (modifier) increases the Marshall stability values and bulk density values are increased and decreases, where stability is found maximum at $30.22 \mathrm{kN}$ for $9 \%$ sulfur at $5 \%$ bitumen content and density of $2.42 \mathrm{~g} / \mathrm{cc}$ for plain and modified bitumen at 3\%, 6\% and 9\% sulfur addition at $5.5 \%$ bitumen content respectively.

It is also observed that the volume of air voids, VMA decreases; theoretical density remains constant, whereas Volume of bitumen, VFB decreases.

\section{CONCLUSION}

On the basis of observation and analysis of Marshall Test properties using sulfur, the flowing conclusions are drawn.

$>$ The Marshall Stability value is found maximum of $30.22 \mathrm{kN}$ for $9 \%$ sulfur at $5 \%$ bitumen content which is more than plain bitumen.

$>\quad$ The bulk density is also found maximum having $2.42 \mathrm{~g} / \mathrm{cc}$ for plain and modified bitumen at 3\%,6\% and $9 \%$ addition of sulfur at $5.5 \%$ bitumen content.

$>$ It is also observed that air voids decrease, which is required for better strength and service life of the pavement and the VFB is increased by addition of bitumen. 
$>$ As per MoRTH, Optimum Binder and modifier content is found to be $5 \%$ and $9 \%$ respectively.

$>$ Modification of Bituminous concrete mix has resulted in maximum stability with less bitumen content, which solves the world oil crisis.

\section{ACKNOWLEDGEMENTS}

I am very thankfull to Noorul Hasan, Omar Jeffrey Mawlong, MD Belal and Pooja M S, UG Students of Department of Civil Engineering, GCE, Ramanagaram for their cooperation in my work.

\section{REFERENCES}

[1]. Abdelaziz Mahrez., and Mohamed Rehan Karim: Rheological Evaluation of Aging Properties of Rubber Crumb Modified Bitumen, Journal of the Eastern Asia Society for Transportation Studies, Vol.5, 2003.

[2]. Jyh-Dong Lin, Shih-Huang Chen, Pei Liu, \& Jian-Neng Wang: Modified Toughness used to Evaluate the Effect of Polymer Modified Asphalt on Stonic Mastic Asphalt, Journal of the Chinese Institute of Engineers, vol. 27, No. 7, pp. 1013-1020, 2004.

[3]. Benson, J.R: New Concepts for Rubberized Asphalts Roads and Streets, April, 1955.

[4]. Robinson, H.L., Taylor, M.B. and Tosh, D.J: Toughness and Tenacity Analysis of Bitumen, Highways, U.K., Jan 1991.

[5]. Madzlan B.Napiah, Ibrahim Kamaruddin, Yasreen Gasm: The Creep Performance of Base and Polymer Modified Bituminous Mixes Containing Different Types of Sand as Fine Aggregate, Journal of the Eastern Asia Society for Transpotation Studies, Vol. 8, 2010.

[6]. H. U. Bahia., D. I. Hanson., M. Zeng., H. Zhai., M. A. Khatri., and R. M. Anderson: Characterization of Modified Asphalt Binders in Superpave Mix Design, Transportation Research Board, National Research Council, National Academy Press Washington, D.C. Vol. 459, 2001.

[7]. Bindu C.S \& Dr. K.S.Beena: Waste Plastic as a Stabilizing additive in Stone Mastic Asphalt, International Journal of Engineering and Technology Vol.2 (6), 2010, 379-387.

[8]. V. S. Punith and A. Veeraragavan: Behavior of Asphalt Concrete Mixtures with Reclaimed Polyethylene as Additive, Journal of Materials in Civil Engineering, Vol. 19, No. 6, June 1, 2007.

[9]. Punith.V.S and Veeraraghavan.A: Fatigue Characteristics of Recycled Plastic Modified Bituminous Concrete Mixes, Highway Research Bulletin, No.70, and Page 11-29, 2004.

[10]. H. Von Quintus., J. Mallela., and M. Buncher: Quantification of the Effect of Polymer Modified Asphalt on Flexible Pavement Performance, in Proceedings of 86thAnnual Meeting, Transportation Research Board, Washington DC, pp.21-25, 2007.

[11]. Taher Baghaee Moghaddam, Mohamed Rehan Karim and Mahrez Abdelaziz: A review on fatigue and rutting performance of asphalt mixes, Available online at http://www.academicjournals.org/SRE
[12]. Denning.J.H and Carswell.J: Improvements in Rolled asphalt Surfacing by the addition of Organic Polymers, Department of the Environment, Report LR989, Transportation Road Research Laboratory (TRRL), Crowthrone, 1981.

[13]. Sabina, Tabrez A Khan, Sangita, D K Sharma and B. M Sharma: Performance Evaluation of Waste plastic/Polymer Modified Bituminous Concrete Mixes, Journal of Scientific \& Industrial Research, Vol.68, pp. 975979, November 2009.

[14]. Ministry of Road Transport and Highway (MoRTH): Specifications of Road and Bridges Works (Third Revision), IRC; New Delhi, 2001.

[15]. Ayman M. Othman: Incorporation of White Cement Dust on Rubber Modified Asphalt Concrete Mixtures, International Journal of Civil \& Environmental Engineering IJCEE, Vol.9, No. 10, pp.40-51.

\section{BIOGRAPHIES}

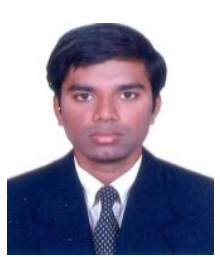

Poorna Prajna S, is working as Assistant Professor in Department of Civil Engineering, Ghousia College of Engineering, Ramanagaram from past 5 years. Also carrying research in present area of bitumen modification.

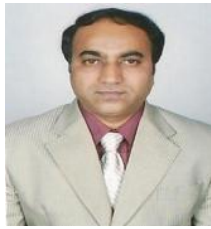

shape factors.
Dr. Mohamed Ilyas Anjum, is working as Professor, Head-(Civil) and Vice-Principal at Ghousia College of Engineering, Ramanagaram, having an experience over 27 years. Also, guiding research in present area of bitumen modification and aggregate

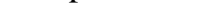

.

